\title{
Roman Husarski
}

Jagiellonian University (Poland)

\section{From Villain to Superhero:}

\section{The Image of the North Korean in Contemporary \\ South Korean Cinema}

\begin{abstract}
Confidential Assignment (Kongjo, Kim Sung-hoon), released on January 18, 2017 between DPRK nuclear tests, tells a story of two special agents. One is from North Korea and the other one from South Korea, and they unite to fight against a common enemy. Extraordinarily, the North Korean agent is portrayed as more formidable than his South Korean counterpart who is unable to match him in every field. Also, the North Korean agent is portrayed by a Korean super star, Hyun-Bin. In this paper, I analyze two other similarly themed movies: The Net (Kŭmul, Kim Ki-Duk) and Steel Rain (Kangchölbi, Yang Wooseok). All of them were released recently and were huge commercial successes in South Korea. The aim of the following paper is to show and analyze the evolution of the image of North Korean characters in South Korean cinema. During the analysis, the question of how the change from villain to super hero was possible is answered. The way in which the movies talk about inter-Korean relations and how they portray both countries is particularly important to understand the current political sentiments in the Peninsula and how it can affect the Moon Jae-in presidency.
\end{abstract}

Keywords: cinema and politics, hero and villain, political myth, South Korean cinema, ideology, propaganda

\section{Introduction}

Since the end of armed conflict on the Korean Peninsula in 1953, the Republic of Korea (RoK) and the Democratic People's Republic of Korea (DPRK) still remain officially at war. Both countries are still separated by the strongest guarded border in the world. In the conditions of strict separation, it is largely the cinema that shapes the attitudes and imagination of the people. Throughout recent history, many South Korean artists and film directors have been trying to deal with the trauma of a divided nation. 
The subject of North Korea from the very beginning has had a unique political significance. Cinema often reflects dominant ideologies in dealing with North Korea. Film becomes a platform for the realization of the political myths. This wide and complex topic can be analyzed in many ways. One way takes a look at the way the hero and villain were portrayed in the movies dedicated to North Korean issues. This binary composition is crucial to understand how South Korean perspectives have been shaped by the cinema. The aim of this article is to present the evolution of the North Korean characters on the silver screen and to explain how such a dramatic political change could be possible. The importance of this phenomena should not be omitted in the context of current South Korean politics.

This analysis first presents the meaning of the hero and villain and how this concept structures imagination and what is their relation and significance for the Korean sociopolitical context. Then, on selected examples, it is investigated how the model has been implemented in the Korean cinema history since the division of the Peninsula until today.

The strongest case of how the imagination of the film makers had been constrained by political ideologies comes from the times of the South Korean authoritarian rulers when anticommunism became a country's dominant ideology. The cinema could realize its principles in the most efficient manner. Based on the anticommunism ideology, the South Korean hero was to protect the nation from the dangerous virus which was coming from the North and which was changing good Koreans into villains. It was presented as a conflict between good and evil. This binary opposition was aimed to explain why the division of the nation happened and why it was necessary to maintain it. It was yet another way to legitimize the new government.

However, the dominant discourse changed radically after the establishment of the socalled "Sunshine Policy". Proclaimed in 1998 by Kim Dae-jung, this new way of policy tried to find reconciliation between the two Koreas (Marszałek-Kawa, 2003). It was during that time when North Korean characters were no longer portrayed simply as unsympathetic, uncivilized villains. It became more common to portray North Koreans in a friendlier way - more as brothers than enemies. Anticommunism was replaced by national ethos which filled new South Korean cinema. Although, formally the directors were freer, one political ideology was replaced by the other. It was during the progressive politics of Kim Dae-jung when in DPRK-related cinema it became difficult to distinguish who the heroes and villains are. Despite the official end of the "sunshine policy" in 2008, the tendencies of South Korean cinema did not change. Paradoxically, after frequent DPRK nuclear threats, this positive image intensified.

For decades, South Korean cinema presented North Koreans basically as enemies of the RoK nation. The tendencies started to change during the so called "Sunshine Policy". Throughout the years, the image of the North Korean in South Korean cinema has radically evolved. Today, South Korean cinema is no longer shaped by a Cold War polarity nor is it driven by an anticommunist film theme. Today, as it can be clearly observed in movies 
like The Net (Kŭmul, ${ }^{1}$ Kim Ki-Duk, 2016), Confidential Assignment (Kongjo, Sung-hoon Kim, 2017) and Steel Rain (Kangchölbi, Yang Woo-seok 2017) North Korean characters are more often portrayed as heroes than villains. ${ }^{2}$ In addition, all of these films achieved a financial success (Gu Geon-u, 2016). Furthermore, the current ideological trends on the ground in cinema are much closer to the discourse proposed by South Korean progressives than conservatives and are strongly supported by president Moon Jae-in's policy toward North Korea.

\section{The Political Meaning of Hero and Villain in Cinema}

The film historian Richard Taylor writes "Every cinema has its stereotypes of good and evil, personified in the archetypal hero and villain" (Taylor, 1997, p. 50). J. Belton remarks that overcoming a villain is a common goal for characters in the Hollywood narration (Belton, 1994, p. 24). Others indicate that the social utility of the hero and villain dualism is a very common narration in cinema (Cook, 2012,p.41). In popular movie genres, like action cinema and western, the contrast between two characters represents two attitudes toward society. The hero is the one who protects the order and the norms as well as one who brings balance. The villain is the one who threatens the stability of the society and who challenges the status quo. If the hero represents order of society, the villain represents anarchy. This binary composition bring us to "mythical reality" (Schatz, 1981, p. 41). The fight, which can often be described as between good and evil, can take different forms and can be presented in multiple manners. It manifests not only in the characters' behaviors but also in the symbolic landscape. Therefore, the villain would be shown as an outcast, as someone who lives in a place outside of society such as in the mountains or woods. This common representation could be understood as a conflict between civilization and wilderness or simply between man and nature. This is also a reason why so often the construction of the villain is synchronized with the process of dehumanization "which divests people of human qualities or invests them with bestial qualities" (Bryant, Oliver, 2009, p. 105).

It should also be noticed that the hero and villain model in Western cinema differs from that in Korea. Whereas individualism is one of the main characteristics of the hero in the West, a perfect representative of the collective is found in the Korean hero who would be defined by idealized features of the nation (Min, Joo, Kwak, 2003, pp. 1-9). The interest of the hero would also be related to the group, even when he is fighting against government authorities. Loyalty and sacrifice are some of the ideal characteristics (Lee, 2015, p. 86). However, from the beginning, the ROK film industry was mimicking Hollywood productions

1 In this text, McCune'a-Reischauer Korean language romanization system is used with the exception of personal names popularized in other styles.

2 This paper focuses on movies the author has chosen as representative, but the motives of the DPRK can be found in many others, so this text does not exhaust the complex and broad topic. 
and drama solutions (Chung, 2014,pp. 98-120). With all the entertainment strategies and westernization, Kim Hie-yoon points out that cinema was always considered, both before and after liberation, as strong tool for promotion of political ideas (Hie-yoon, 2015, p. 8).

Be defeating a villain, the hero is proving that his values are stronger which brings the idea that the mythological conflict presented on the screen has a broader, political meaning. As noticed by W. Wright, its aim is to bond the audience to a particular social order. The researcher also argues that those structures do not exist independently but are dependent on the dominant power institutions (Wright, 1975,pp. 11-15). A film is a powerful medium which affects the lives of individuals and their political attitudes by creating collective experiences (Mutz, 1998, pp. 62-99). Ernst Cassirer warned how effective a myth can be in the hands of the state as it can transform the language, ethical values and meanings. According to the Jewish philosopher, a myth even "can be manufactured in the same sense and according to the same methods as any other modem weapon-as machine guns or airplanes" (Cassirer, 1946, p. 282). A film, as a method of efficient propaganda and a popularizer of myths, has been used by different authoritarian regimes, and North Korea would be a radical example of one (Schönherr, 2012). However, the political power of the medium should not be ignored in more democratic systems in which different ideologies are clashing. Its importance in affecting or representing the political realm is always actual.

In the comments of Ferdinand de Saussure's model of language, $S$. Hall points out that the binary opposition is fundamental to produce the meaning in the viewer which explains why it is so widespread. However, he presents that the understanding of the contrasted images is flexible and can be modified. "If the relationship between a signifier and its signified is the result of a system of social conventions specific to each society and to specific historical moments - then all meanings are produced within history and culture" he writes (Hall, 1997, pp. 30-32). Thus, the problem of how the depiction of North Korean characters changed over time in South Korean cinema and how it was related to politics shall be examined

\section{Before the "Sunshine Policy" 1945-1998}

On August 15, 1945 the Japanese forces withdrew from the Korean Peninsula which ended 35 years of occupation, but it happened not without a price. Against the will of the Korean people, the country was divided in half along the $38^{\text {th }}$ parallel by the USSR and the United States. When the Soviets established their government in the North, the Americans did the same in the South. Syngman Rhee, the former Prime Minister of the Provisional Government of the Republic of Korea in Shanghai, a holder of a $\mathrm{PhD}$ from Princeton University, and a Christian, was chosen by the occupying forces to take power. On August $15^{\text {th }}$, the Republic of Korea was formally established with Rhee as president. He held office until 1960 (Peterson, Margulies, 2010, pp. 154-176).

Syngman Rhee's ideology was concentrated on independence and anti-colonialism. He was a strong anti-communist who initiated several campaigns against the influence of the 
USSR in South Korea. Despite the fact that the scale of repression and control never reached the level of the Kim Il-sung dictatorship, thousands of people were killed and imprisoned - especially after the postwar anti-guerrilla campaigns (Lankov, 2013, pp. 109-110). Anticommunist ideology played an important role in the Republic of Korea, and it also affected cinema. However, the term anti-communist film (pan'gongyonghwa) is not found in any Korean dictionary, and its nature is still discussed by several scholars. Some Korean scholars argue that it is indistinguishable from the war film genre (Cheol-hui, 2016, p. 6). Some consider it as a subgenre of propaganda films, such as Yu Hyeon-mi, who has argued that the aim was to encourage or to accommodate anti-communist ideas. Others argue that the anti-communist film does not exist as an independent film genre, but only some common motifs of it can be found in different genres - from action to melodrama (Cheol-hui, 2016, pp.6-7). According to 1977 publication, Korean Film Data Collection, between 1949 and 1960 a total of seventeen so-called anti-communist films were made (Ae-gyung, 2011,p. 179). However, this list could be longer or shorter depending on the criteria for classifying the anti-communist film. For example, while it is not clear for some movies that the main idea of their production was to counteract the communist ideology, it was possible to classify them as anti-communist by containing of an ideological slogan.

During the postwar occupation, Americans paid much less attention to the local cinema than the Soviets did in the North. Also, Syngman Rhee was not as interested in supporting or controlling the cinema to the level as was the case in the DPRK. Although there was an institution of censorship, cinema was to be primarily for entertainment, and the productions of which were focused on profit. For South Korea, Hollywood was a big inspiration and the idea of the free market was very present. However, not all artists appreciated the Americanization of the local cinema market, and many escaped to the North due to a greater sympathy for communism and considering the regime in the North as more legitimate - some even came to Pyongyang with stolen American film equipment (Armstrong, 2002, pp. 11-13).

Generally speaking, the movies produced during the Syngman Rhee presidency were not as anti-Pyongyang as one might expect. Probably the strongest of the anti-communist films would be the propaganda documentaries produced after the Yeosu-Suncheon Rebellion. The rebellion started just two months after the establishment of the new government, and it was a surprise and threat for Rhee Syngman's government. The documentary movie, The Yeosu Suncheon Rebellion Incident (Yǒsusunchǒnballansagŏn, 1948, Kim Hak-sung, Shim Jae-heung) was blaming North Korea for inspiring and financing the communist guerrilla fighters (Cheol-hui, 2016, pp. 8-12). However, films from the time of Syngman Rhee were concentrated more on propagating anti-Japanese ideology than on anti-communism. The division of the Peninsula was seen mainly as a tragedy with roots in the colonial period, meaning that all Koreans, both in the North and South, were victims who shared a common enemy. However, the cinema of the RoK until the 1960s was not ideologically homogeneous, and during that time, many different DPRK related themes can be found. 
One approach took form in stories of the divided families which become so popular that some scholars postulate a special term for them: "separation (pundan) melodrama"(Aegyung, 2011, p. 186). One of the earliest examples of this type is Breaking the Wall (Sŏngbyŏkŭl Ttulko, 1949) by Han Hyeong-mo. Set in the context of the Yeosu-Suncheon rebellion of 1948, it portrays the ideological conflict between two friends who graduated from the same school. Young-pal is a communist and Jip-gil is a nationalist as well as a second lieutenant in the South Korean Army. At the beginning they only try to persuade each other, their conflict intensifies as time progresses. Eventually, politics divides the two friends and it ends tragically. Communism is presented as a destructive, anti-state and anti-human ideology. Young-pal believes that the end justifies the means, and he rejects his friend's pro-democracy arguments. At the moment when he definitively determines his attitude, he can be described as a villain. He no longer belongs to society, because he does not respect its principles. The communists are portrayed as a serious threat to the social stability. The use of terror and violence to achieve their goals, represents chaotic force which should be stopped - by loyalty to the state.

This sort of ideological conflict motif in early South Korean cinema is repeated many times. For example, in the movie Arirang, produced in 1954 by Lee Kang-cheon, set in North Korea during the Korean War, two sisters decide to hide and help two wounded Americans. Their actions are discovered and the question is raised as to whether communist ideology does not take away the humanity of a person. The dehumanization strategy, one of the aspects of describing villains, is strongly connected to those who accept communist ideology.

One of the most interesting North Korean themed movies was Piagol (1955, Lee Kangcheon). Especially after the war, Rhee Syngman's government was still fighting with communist soldiers who remained in the South as well as with North Korea supporters. The uprising, partisans and enemy ideology created anxiety and paranoia in the government as well as in society and the cinema was reflecting that. The film depicts a DPRK partisan camp hiding on Jirisan mountain (Piagol is the name of one of its peaks). Far from the big cities and in dangerous environment it makes the perfect villain landscape.

In Piagol the main character Ae-ran, a young and idealistic girl, joins the partisans, but over time she becomes disillusioned with the ideology after helping the communists terrorize local villagers. She discovers that communism will not resolve Korea's problems, but finds that it is also disastrous for the soul. In the final scene she leaves the camp and goes to the mountains. Interestingly she rejects the temptation to be a villain, but also did not fully decide to bea hero, at least in the censor's eyes who ordered changes in the last scene. Lee Kang-cheon had to add patriotic motives in the re-released movie, and so we see an image of the Korean flag which assures the viewer that Ae-ran was on her way to South Korean patriotism. To avoid controversy, Lee would be more straightforward in his next movies. He would concentrate on presenting war heroes and would later be called the "standard bearer of the anti-communist film" (Peirse, Martin, 2013, p. 54). However, the original scene is 
interesting and is reminiscent of an American Western in which the hero, in order to fight with the villain, needs to break the rules of society, so he is in fact independent of it. This impression is usually strengthened by the lack of home and family of the main character (Cook, 2012, p. 24). In the original ending, Ae-ran like the typical western hero, did not return to society, but rather chose an individualistic path.

From these few examples it can be seen that in the time of Rhee Syngman it was not simply a border between Koreans from the North and the South which marked the lin between heroes and villains, but ideology. Both South and North Koreans were presented as possessed and evil when they chose communism. The cinema mostly explored this issue, which in some cases led to complex psychological analysis (such as in Piagol). The consternation of war intensified the fear of communism and the hidden enemy narrative was very present. In the second half of the 1950's, along with the increase of government control, anti-communist cinema had lost its momentum (Ae-gyung, 2011, p. 180).

However, it all came back with the military coup and Park Chong-hee's (1961-79) government. The new military rulers strengthened censorship and imposed an ideological framework onto it. On January 20, 1962 the Motion Picture Law was established. As we can read in Korean Film: History, Resistance, and Democratic Imagination:

The key point of this law was "protecting and fostering Korean films" by setting up rigid requisites for the film business and creating an import quota system. During this period, censorship began to repress the creative zeal activated in the filmmakers of the previous period, and the import quota system created a flood of unimportant movies, negatively coined "quota- quickies" (Min et al., 2003, p. 62).

Although there was no state movie industry in South Korea as in the DPRK, the new law pushed to centralize the cinema business. In 1962 alone, seventy-two movie companies merged into sixteen. Because of censorship, the commercial companies had to be careful if they wanted to make a profit (Chong-hwa, 1997, pp. 134-136). The private industry responded to the strict censorship by producing so-called "revolutionary films" (hyŏngmyŏng yŏnghwa) - war movies which were concentrating on Park Chung Hee and other military leaders' war successes. In other ways, they spread imposed political myths of the new government. This types of film in which the army was involved served to strengthen the new ruling junta.

In these movies, North Koreans were portrayed as typical villains, treacherous and brutal, often cartoonish and fanatical. On the one side, there were brave and benevolent soldiers and on the other, insidious monsters without morals. For example in The Marines who Never Returned (Toraojiannŭn Haebyŏng, 1963) directed by Lee Man-hee, the DPRK soldiers shoot a mother and child in the battleground. A South Korean soldier risks his life to try and save the child, a young girl. Later she would become the mascot of the military squad. The South Korean army is portrayed as a benevolent force which takes care of the innocent. In another scene, South Korean soldiers discover a site where civilians were brutally tortured 
and killed. The viewer hardly sees any North Koreans on the screen which has a strong mythical effect. It is almost as if what is being dealt with is some unclear, impersonal force, which acts like a beast. The viewer discovers North Koreans through their murderous and inhuman actions. In effect dehumanization is employed yet again.

During the reemergence of DPRK theme in movies the espionage film genre became popular. The most prominent of these is Lady in Dream (Mongnyŏ, 1968) filmed by Im Kwon-taek. Joanna Elfving-hwang noticed that Andrew Tudor's concepts of "secure horror" or "paranoid horror" could be helpful to understand this type of film which refers "to a threat "from within" - one that cannot be seen or detected because it is rendered invisible by its very familiarity to those around it. In cinematic narratives, such threats can be the enemy within, such as a spy who looks like the rest, but unexpectedly turns on those around them and who remains undetected until it is too late (Elfving-hwang, 2015, p. 13). The viewer could not be sure if the hero would not turn in to the villain suddenly. If North Korean spies could be anywhere, then it was necessary for a strong government to protect its citizens. In this way, Park's military command found legitimacy.

Park Chong-hee's discourse would begin to slowly change after his assassination in 1979. General Chun Doo-hwan's government was also authoritarian, but it took a different approach toward the DPRK and tried to bring both countries closer. As a result of his "Korean People Harmony Democracy Reunification Program", anti-communist education in schools was replaced by a friendlier reunification program. The perception of the North Korean was also affected by the democratization process after 1987. Still, a revolution would not come until the "sunshine policy".

\section{North Koreans Are Our Brothers 1998-2015}

The 1990's brought huge economic growth and globalization for South Korea. The South Korean cinema business became one of the most powerful ones in the Asian film industry. Many films achieved not only high commercial success, but also the recognition from film critics all around the world. The elements of success include the use of American movie conventions, huge budgets, elements of localism and historical themes, as well as the individualistic styles of each director. Critics described the new phenomenon as Hallyuwood, fusion of Hollywood with Hallyu, or Korean wave (see Chi-yun, Stringer, 2005). However, the significant changes in the DPRK theme in cinema can be observed especially from the establishment of the so-called "sunshine policy" (1997-2008). It began with the initiative of South Korean President Kim Dae-jung and was designed to bring together both nations with the long term goal of reunification. It was the first time when Korean progressivist left-wing ideology, which can be characterized by optimistic views on the inter-Korean dialog and nationalistic stance came to power (Myers, 2010, p. 159). During this period, political and cultural dialogue began, and families separated years ago could meet again. These political changes and hopes strongly affected cinema. 
The 1999 film, Shiri by Kang Je-gyu was a block-buster action film about North Korean spies. ${ }^{3}$ It seemed like a classic espionage movie and good example of Andrew Tudor's "paranoid horror". However, the film plays on the viewer's emotions, going beyond the usual templates. The North's agent, Lee Bang-hee (played by Yunjin Kim) after cosmetic surgeries lives a double life in South Korea. Her persona is portrayed beyond the classical characterization of a North Korea spy. She is deadly, but also beautiful and her tragic situation makes viewers sympathize with her. Myung-hyun Lee (her South Korean pseudonym) falls in love with a South Korean special agent, Yu Jong-won, who is in charge of her case. Both of them would like to tell the truth to each other but they ultimately fail. The internal struggles of characters reveal numerous moral dilemmas. The question arises whether the heroes are fighting for what they truly believe in or for what they have been taught to do. Eventually the division between hero and villain blurred. It is the division of the motherland which seems to create a tragic effect. The heroes are trapped in false identities, and they feed themselves with lies that will lead to their self-destruction. The artificial nature of this situation is symbolized using a fish metaphor. Shiri refers to Coreoleuciscus splendidus, a fish which swims in the waters of both North and South. Another symbolic scene shows Myung-hyun giving Jong-won a pair of kissing gourami fish. This species survives in pairs which cannot live without the other. When one dies, the other dies too. This scene suggests that reunification is the only choice for Koreans.

On a wave of political thaw, between meetings of separated families and mutual promises, Park Chan-wook presented J.S.A. (Kongdonggyŏngbiguyŏk, 2000). The movie became a huge commercial success in 2001 and had become the highest-grossing film in Korean film history. Set in the DMZ, the soldiers guarding both sides of the borders overcome their fears and prejudices and secretly become friends. The dehumanizing stereotypes were cut off and ideological differences of both sides were neglected. The whole story ends tragically with a shooting incident - the secret friends are discovered by a soldier, who was not privy to the initiative. However, the viewer, a Swiss-Korean investigator named Sophie, did not know the details of the event. The ironic ending shows the official media deciding not to present the truth, because it would contradict the statement of both countries, which were officially at war. JSA explores the possibility of political friendship between two countries which mirrored the dominant Korean left-wing politics at the time. During secret meetings, South and North Korean guards exchange goods to break their hostility and gain trust. This scene reflects the Korean left-wing nationalistic view on the economical engagement between two countries which would ideally replace all animosities, terminate the DPRK nuclear program and bring prosperity to all. In reality, all efforts came to be one sided and were very costly to South Korea (Martin, 2004,pp.633-683). The movie tried to deconstruct the anticommunist film scheme not only by showing good communists, but also by accusing

3 Movie plot based as an inspiration for Korean drama Iris (Airisŭ) directed in 2009 by Kim Kyu-tae and Yang Yun-ho. 
people who were defending such binary views. In one example, one of the commanders who tries to prevent Sophie's investigations says that in the world, there are only two types of people "commie bastards and the commie bastard's enemies". He is also the one who pushes her to stop her work. The villain in the movie is not narrowed only to this unnamed commander, but also takes form as the state. Both countries are to blame for maintaining artificial barriers. States are impersonal and personal responsibility is effectively removed. Ideologically, the film encourages the viewer to dispense with all of the past dualistic views and rather concentrate on the unity of the Korean race.

Four years later, Kang Je-gyu directed Brotherhood of War (T'aegŭkki hwinallimy $\breve{o}^{4}$ ). It was principally a war movie but with an ideology very similar to J.S.A.. During combat, two brothers get into the enemy trenches. In the final battle they meet on the battlefield. During the fighting, the viewer is unable to distinguish the protagonists due to the fast motion of the camera and flying debris. All the main characters do not simply fall on one end of the hero/villain binary. Although some soldiers express anti-communist sentiments, it appeared that this view was based only on revenge. The ideological differences between both countries are not analyzed. Furthermore, the film suggests that ideological divisions are a complete façade and the root of all conflict which leads in to the slaughter. It turns out that Koreans were manipulated by states which made them forget about their same blood. Who is to blame? In the Brotherhood of War, the foreign superpowers seem to be fully responsible for the tragic separation of the nation.

The lack of greater reflection in the South Korean cinema on the social and political realities in DPRK may come as a surprise. Crossing (K'ŭroshing, 2008) directed by Kim Tae-gyun may seem to fill this gap. Film touches on the topic of the North Korean famine (1994 to 1998) which led to thousands of people abandoning their homes - although most of them did not get further than China (see Haggard, Noland, 2006). Struck by the poverty and illness of his wife, Kim Yong-soo is forced to leave the North. The film is dark and gloomy, convincingly showing the oppression of the brutal DPRK police on the citizens and the suffering faced by those who decided to flee. It realistically illustrates how difficult it was for such people to understand the outside world and how the Pyongyang regime created, to use Kang Chol-hwan's metaphor, an "aquarium" in which he enclosed his residents (Chol-hwan, Rigolot, 2005). This maladjustment is especially shown in scenes when the main character is trying to adjust to South Korean employment system or through his contacts with Protestant missionaries, who are the first to help the defectors while expecting faith in Jesus in return. Interestingly, Kim Yong-soo is a North Korean hero who struggles to survive in hostile environments. All heroes are portrayed as the victims of a cruel system, as people who need compassion and help. Although North Korea is blamed for the character's personal tragedy, South Korea does not succeed with the adaptation program. Yet again, the movie

\footnotetext{
4 Direct translation of the movie is: The flag is waving.
} 
echoes the political situation. Crossing premiered when the Sunshine Policy had officially ended. It became clear the attitude of the DPRK would not be changed. The new president Lee Myung-bak represented the conservative revival in the politics. However, despite a more conservative take than previous movies, the film disappoints with the inconsistency of declining more political explanation. The viewer does not find out exactly why the DPRK is a poor and oppressive country.

The Crossing was more realistic in its approach than the other two movies, but there was no more going back to the pre-sunshine cinema. The movie portrays the North Koreans one more time as brothers. All three presented films are also characterized by a pessimistic end. As the division is fundamentally caused by international politics, the foreign powers benefit from it and the Koreans lose from it. Anti-American sentiments, if not openly depicted, is suggested. In these films, blood ties are of prime importance, and ideological issues are not raised at all. There is no mention even of who started the war. The most important difference is that one country is richer than the other. Bo-Myung Seo, when writing about the sunshine cinema, argued that this movie shows the "success, if not the triumph, of capitalism over socialism" (Seo, 2018). The contrast in presenting both sides can serve this interpretation.

\section{The Most Recent Cinema 2016-2017}

Nationalism, anti-Americanism, and fatalism are common themes in the works of Kim Ki-duk, who, due to his use of drastic forms of expression, is called the "bad boy" (nappün namja) by Korean critics (Hyun-jun, 2008, p. 3). Kim Ki-duk criticized the presence of the US forces in Korea in the film Address Unknown (Such'wiinbulmyŏng, 2001). In this movie, an American soldier treats his Korean girlfriend as a prostitute, and in exchange he gives her money for an eye operation. In the end, she prefers to get rid of her sight so as not to owe anything to an American soldier. In subsequent films, the director also criticizes the politics of the Republic of Korea. In Coast Guard (Haeansŏn, 2002) he attacks the inhumane conditions in the South Korean army and anti-North Korean propaganda which turns people into killing machines. The full ethos of Korean leftist nationalism is expressed in The Net (Kŭmul, 2016).

The main protagonist of the film is a North Korean fisherman (portrayed by the charismatic Ryoo Seung-bum who perfectly mimics the North Korean accent,), who by unfortunate coincidence gets captured in South Korean waters. The National Intelligence Service of South Korea is convinced that once a man sees the beauty of democracy, he will not want to go back, but the fisherman literally refuses to open his eyes and demands to be sent back to the DPRK. The struggle for his soul begins. The story is an condemnation against the South Korea's systemic corruption and hypocrisy. As it will turn out, the Republic of Korea's oppressive system is not so very different from the North Korean one. This time, the differences between the two countries are not only reduced to economic issues, but also to moral ones. 
When the fisherman finally sees Seoul and life in the South, he cannot find anything really worthy. South Korea turns out to be a country plunged deep in economic problems, drunkenness, prostitution and violence. Youth adopt the worst patterns from the West, and the police, instead of serving the nation, torture and mistreat the prisoners. The Republic of South Korea seems to lack the morals so present in the attitude of the fisherman.

In The Net, Ryoo Seung-bum's character is a model hero. He turns out to be a master of martial arts, with strength and endurance much more higher than the agents from the South. It is clearly an image of a macho man who can escape a prison by himself and also save a woman under oppression. The villain turns out to be a conservative South Korean police officer. As an obstacle to unification, he is defeated in the final scene. While Kim Ki-duk's criticism of the South Korean system may be justifiable, the ideological attitude of the director distances him from a realistic assessment of the situation. The political system of South Korea, with all of its problems is not even close to the totalitarianism of the DPRK (see Lankov, 2013). Characteristic of South Korean left-wing ideology, the state is vilified yet again.

The perfect example of another macho North Korean archetype is realized in Confidential Assignment (Kongjo, 2017) directed by Kim Sung-hoon. The film, which was released in the interval between successive nuclear tests by Pyongyang, talks about the alliance of the two countries to capture a dangerous criminal, a money counterfeiter and a traitor to the DPRK regime who is hiding somewhere in Seoul. The DPRK sends a special investigation team to the Republic of Korea to join with the South Korean intelligence. Two agents must work together. The North Korean is represented by the agent Im Cheol-ryung who is skillful, determined and handsome. He is played by the super star Hyun Bin. The South Korean agent, Kang Jin-tae seems like his exact opposite. He is clumsy, funny and cowardly. He is played by Yoo Hae-jin who is famous as a comedy actor. In the fight scenes, it is the North Korean agent who does almost all of the work. The way he fights by beating dozens of enemies leaves no doubt that he is a super hero.

The differences do not end with physical abilities. Kang Jin-tae represents all of the problems of living in a consumeristic, industrial and non-ideological society. He struggles to wake up, has existential doubts and a problem with alcohol. He seems like a cynic next to Im Cheol-ryung. When he tries to confront him with political issues, the North Korean agent always has a ready answer. "Do you know what South Korea's debt is? ...At least we are poor equally". He always seems to have the last word. When Kang Jin-tae criticizes the cult around their dear leader, he answers with indignation, "Do not insult the Republic!" Despite the fact that both sides must cooperate to defeat the common enemy, the viewer does not have any doubts about which side is more powerful and more moral. The whole film shows South Korea's lack of faith in its own strength. Ideologically, the main villain is not only a killer, but also a defector. It seems that the traitors of the North Korean state must be punished. An apology of the DPRK also manifests itself in the North Korean commander who represents state authority as a good uncle. 
Steel Rain (Kangchŏlbi, 2017) by Yang Woo-suk is another example of a model of cooperation between the two countries. The movie is an action spy movie, which at the beginning is reminiscent of The Bourne Identity (Liman, 2002). North Korean super-agent Eom Chul-woo (Jung Woo-sung) is ordered to kill a high level DPRK official. In the process, it turns out that he was framed and instead of his original target, Kim Jong-un himself appears on the spot (although his face is never shown, and he is referred to only as "Number One", the South Korean viewer will not have problems in identifying him). As a result of the assassination attempt, a retaliatory attack prepared by the DPRK generals is executed, and almost all people die on the spot. However, the agent decides to act and saves "Number One"s life, as well as two teenage cheerleaders. Suddenly, he finds himself in a situation where he must face both North and South Korean forces. He eventually finds his way to Seoul while he is trying to rescue the unconscious leader.

During his struggle, he encounters the South Korean senior national security official named Kwak Chul-woo (Kwak Do-won). He joins to help him. Both heroes are very different. Again, the agent from North Korea is a real tough guy and a killing machine, while the South Korean representative is an intelligent, yet conceited man. Although he likes to give people advice and thinks highly about himself, he has many problems. He is separated from his wife and his children do not live with him, all the while having problems with his job. The economic difference between the representatives of both countries is clearly outlined. In one scene, Eom Chul-woo consumes large amounts of food, pointing to the poor living conditions in the DPRK. However, he is clearly the real hero who has devoted his life to save the status quo of the Peninsula. Would representatives of the South be capable of such a sacrifice? Once again Steel Rain reveals admiration for the nationalist North Korea ethos.

Another interesting thread is the alliance of both sides in defense of the leader of the DPRK. It is as if the director wanted to say there might be worse options than Kim Jongun. The geopolitical message of the film is also very nationalistic and isolationist because it ends with a vision of a unified peninsula in which the DPRK is the nuclear-military defensive force of Korea. Although the film was made on the basis of a webtoon (a type of digital comic that originated in South Korea), it premiered during the presidency of Moon Jae-in. His pro-unified message could have been important for the public support of Moon's "Sunshine Policy 2.0".

\section{Conclusion}

As I suggested at the beginning, South Korean cinema is no longer shaped by the Cold War polarity. Cooperation of both countries to fight a common enemy or the vision of unification through a confederation model (one state two governments) would not have been conceivable before the "sunshine policy". The motive of ideological differences between both countries is often absent or presented as artificial in recent cinema. The only difference between the ROK and DPRK would be economical ones. Although the simplified image of the North 
Korean villain and the straightforward dehumanization vanish from films, the new image is also problematic as it is ideological and usually represents the Korean left-wing imagination and myths. The image is still stereotypical and strongly influenced by pop culture.

Because of a still strong isolation, persistent propaganda, and the military politics of Pyongyang, the image of the macho North Korean has emerged in recent years. He is no longer a villain, but rather a super hero. The rise of self-criticism in South Korea appears at the same time as a sympathy and admiration for the DPRK can be found in these movies. North Korean characters are usually depicted as strong men, pure, and with impeccable moral principles and appearance. Depicting defectors as criminals may also be worrying. On the other hand, after all these years, these movies show that there is still strong hope in South Korea for unification. Not necessarily in the form of one state, but at least through cooperation or peaceful coexistence. However, the long-term effects of such a policy are not considered.

Taking into account the popularity of these movies, they will be a support for the current Moon policy which is striving to draw both Koreas closer. However, the myths are living their own life now. Being a help for the current government agenda, these productions put pressure for the government to achieve unification. Generally, these images are powerful and they soften the general attitude of South Koreans toward the DPRK. Even when they are threatening us with nuclear power, we should not treat them too harshly - it is better to admire them.

\section{References}

Ae-gyung, S. (2011). Anticommunist War Films of the 1960s and the Korean Cinema's Early Genre-

Bending Traditions. Acta Koreana, vol. 14, No. 1, pp. 175-196.

Armstrong, C.K. (2002). The Origins of North Korean Cinema: Art and Propaganda in the Democratic

People's Republic. Acta Koreana, vol. 5, pp. 1-19.

Belton, J. (1994). American Cinema/American Culture. New York: Mc Graw Hill.

Bryant, J., Oliver, M.B. (2009). Media Effects. Advances in Theory and Research. In Media effects: Advances in theory and research.J. Bryant, M.B. Oliver (Eds.). https://doi.org/10.1017/CBO9781107415324.004 Cassirer, E. (1946). The Myth of the State. London.

Cheol-hui, J. (2016). Han'gukchŏnjaeng chŏnhu pan'gongmunhwa hyŏngsŏnggwa kŭ ŭimi pan'gongyŏnghwarŭl chungshimŭro. Han'gungminjongmunhwa, No. 5.

Chol-hwan, K., Rigolot, P. (2005). The Aquariums of Pyongyang:Ten years in North Korean gulags. New York.

Chong-hwa, C. (1997). Han'guk yŏnghwasa. Seoul.

Chung, S. (2014). Split Screen Korea: Shin Sang-ok and Postwar Cinema. London: University of Minnesota Press.

Cook, C.M. (2012). The Hero and Villain Binary in the Western Film Genre.pp. 1-81.

Elfving-hwang, J. (2015). Disaster Narratives in the South Korean Cultural Imaginary. Korea Journal, vol. 55 , No. 3, pp. 8-29.

Haggard, S., Noland, M. (Eds.). (2006). The North Korean Refugee Crisis: Human Rights and International Response. Washington. 
Hall, S. (1997). Representations, Cultural Representations and Signifying Practices. London: Sage. Hie-yoon, K. (2015). Archives of Ephemera: Cinema and Decolonization in South Korea.p. 239. Hyun-jun, M. (2008). Kim Ki-duk and The Cinema of Sensation. University of Maryland.

Lankov, A. (2013). The Real North Korea : Life and Politics in the Failed Stalinist Utopia. https://doi. org/10.1017/CBO9781107415324.004

Lee, S. (2015). The Power of Cinema on the Korean Peninsula. Global Politics Review, vol. 1, No. 1, pp. 83-94.

Marszałek-Kawa, J. (Ed.). (2003). 34 50-lecie Komisji Nadzorczej Państw Neutralnych w Korei. Toruń: Adam Marszałek Publishing House.

Martin, B.K. (2004). Under The Loving Care Of The Fatherly Leader. North Korea and the Kim Dynasty. New York: St. Martin's Press.

Min, E., Joo, J., Kwak, H. (2003). Korean Film: History, Resistance, and Democratic Imagination. London.

Mutz, D.C. (1998). Impersonal influence. How Perceptions of Mass Collectives Affect Political Attitudes (Cambridge). New York.

Myers, B.R. (2010). The cleanest race. How North Koreans See Themselves - And Why It Matters. New York.

Peirse, A., Martin, D. (Eds.). (2013). Korean Horror Film. Edinburgh.

Peterson, M., Margulies, P. (2010). A Brief History of Korea. In Facts On File.

Schatz T. (1981). Hollywood Genres: Formulas, Filmmaking, and the Studio System. McGrawh Hill.

Schönherr, J. (2012). North Korean Cinema. A History. North Carolina: McFarland \& Company.

Seo, B. (n.d.). Reunifying Identities: North and South in Contemporary South Korean Cinema. Retrieved May 25, 2018, from http://brightlightsfilm.com/reunifying-identities-north-south-contemporarysouth-korean-cinema/\#.WvWZ_YiFPIU

Shin, C.Y., Stringer, J. (Eds.). (2005). New Korean Cinema. New York.

Taylor, R. (1997). Film Propaganda. Soviet Russia and Nazi Germany. London: I.B. Tauris.

Wright, W. (1975). Sixguns and Society: A Structural Study of the Western. Berkley.

The data in this article was collected mostly from the film library of the Hankuk University of Foreign Studies in Seoul and from shared materials by the Korean Classic Film which are available online: http:// www.kmdb.or.kr.

Filmography

\begin{tabular}{|c|c|c|c|}
\hline English title & Korean title & Director & Year \\
\hline Breaking the Wall & 성벽을 뜷고 & Han Hyeong-Mo & 1949 \\
\hline $\begin{array}{l}\text { The Yeosu Suncheon rebellion } \\
\text { incident }\end{array}$ & 여수순천반란사건 & $\begin{array}{l}\text { Kim Hak-sung, Shim Jae- } \\
\text { heung }\end{array}$ & 1948 \\
\hline Arirang & 아리랑 & Lee Kang-cheon & 1954 \\
\hline Piagol & 피아골 & Lee Kang-cheon & 1955 \\
\hline $\begin{array}{l}\text { The Marines who Never } \\
\text { Returned }\end{array}$ & 돌아오지않는 해병 & Lee Man-hee & 1963 \\
\hline
\end{tabular}




\begin{tabular}{llll}
\hline English title & Korean title & Director & Year \\
\hline Lady in Dream, & 몽녀 & Im Kwon-tae & 1968 \\
\hline Shiri & 쉬리 & Kang Je-gyu & 1999 \\
\hline J.S.A. & 공동경비구역 & Park Chan-wook & 2000 \\
\hline The Brotherhood of War & 태극기 휘날리며 & Kang Je-gyu & 2004 \\
\hline Address Unknown & 수취인불명 & Kim Ki-duk & 2001 \\
\hline The Coast Guard & & & 2002 \\
\hline Crossing & 해안선 & Kim Ki-duk & 2008 \\
\hline The Net & 크로싱 & Kim Tae-kyun & \\
\hline Steel Rain & & & 2016 \\
\hline Confidential Assignment & 공조 & Kim Ki-duk & 2017 \\
\hline
\end{tabular}

\section{Author}

\section{Roman Husarski}

MA, roman.husarski@doctoral.uj.edu.pl - PhD student in the Institute for the Study of Religions, Faculty of Philosophy, Jagiellonian University (Poland) 